\title{
The Difference Between Female And Male Leadership
}

\author{
Asma Manzoor \\ Women's Studies \\ University of Karachi \\ \& \\ Naheed Abrar \\ Department of Social Work \\ Urdu University
}

\begin{abstract}
Our society is currently experiencing a period of significant change in the concept of women's role. This change is reflected in the increasing numbers of women who are planning their lives around careers in the work world. As women gradually enter leadership roles that traditionally were occupied mainly by men, the possibility that the leadership styles of women and men differ continues to attract attention. There are specifically no rules for leadership but there are certain skills that every good leader seems to have. In the battle of the sexes, people often find themselves in discussion on the differences between male and female leadership. Indeed, there are different perspectives on this topic ranging from recognition of no differences in style or ability to clear-cut differences based on gender. This article discusses the differences between male and female leadership styles. Since there are different characteristics between men and women, male leadership is often symbolized by an ego-driven form of direction-giving, while female leadership entails more listening and co-operation.
\end{abstract}

$$
\begin{aligned}
& \text { تلخيصِ مقالر }
\end{aligned}
$$

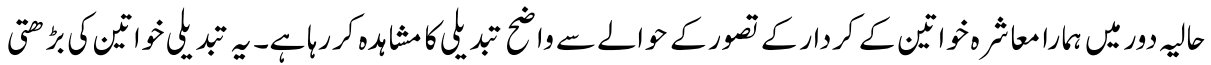

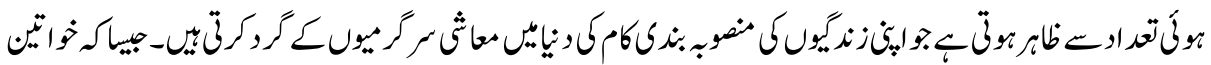

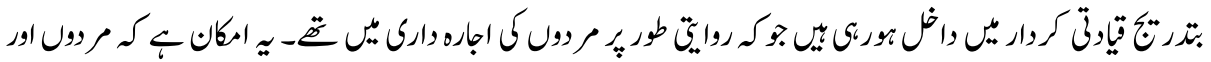

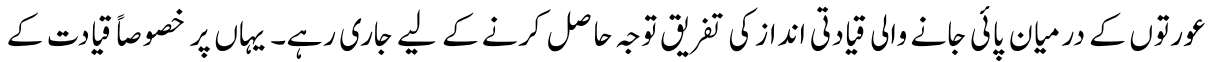

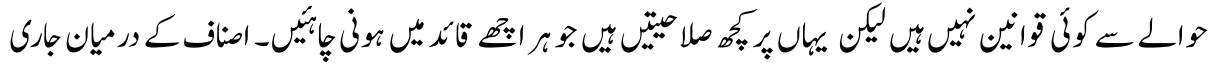

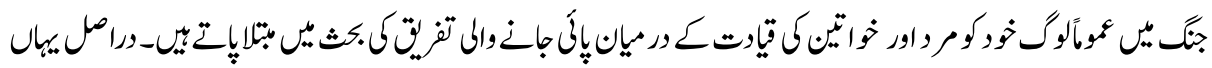

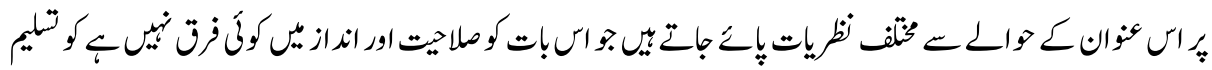

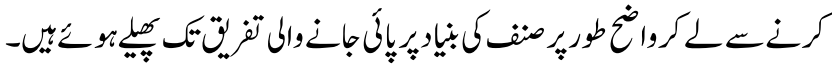

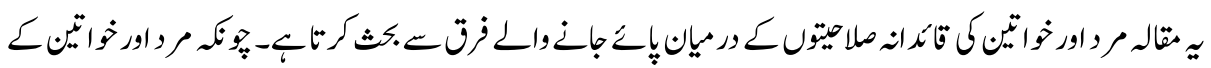

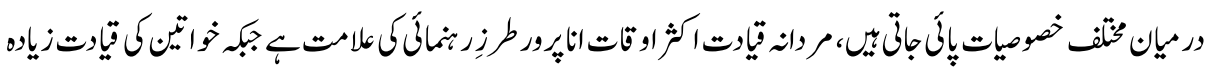

$$
\begin{aligned}
& \text { سنغ اورتحاونس مثر }
\end{aligned}
$$


"We are measured not by what we are, but by the perception of what we seem to be; not by what we say, but how we are heard; not by what we do, but how we appear to do it."

Anonymous

A person does not become a leader by virtue of the possession of some combination of traits, but the pattern of personal characteristics of the leader must bear some relevant relationship to the characteristics, activities, and goals of the followers. Thus, leadership must be conceived in term of the interaction of variables which are in constant flux and change. The persistence of individual patterns of human behavior in the face of constant situational change appears to be the primary obstacle encountered not only in the practice of leadership, but in the selection and placement of leaders.

Stogdill

\section{Introduction}

Women who constitute half of the world population are not fully harnessed as a human resource in the world. Right through history, women have been assigned a secondary status throughout the world. However, the world wars proved to be a turning point in the history of mankind and the participation of women in the workforce has started increasing since then. This trend is observed in both developed and developing countries. Women's role at leadership level is no less important than that of men. Today throughout the world women have entered into traditional male domains such as construction, mining and manufacturing of industrial products. In different countries of the world women were assigned a significant role in nation building activities. The socio economic changes that were set in motion in the globe after world war II provided women with better educational and employment opportunities (Sogra, 1994). Today the educated women have made a landmark in different nonconventional fields like consultancy, marketing, advertising etc. women have also played a decisive role in leadership and the significant increase in women leaders has been facilitated by educational, political, economic, and status changes in our society. Women leaders express the same general leadership traits as men, but may have leadership styles particularly suited to today's needs. In earlier generations women leaders were comparatively few in number, there was an occasional ruler, society leader, head of a family conglomerate usually through inheritance. Women in these position were considered exceptional individuals rather than role models for other women or typical of society's leaders. Today women have a much more significant leadership presence. Looking around the world, we have women head of states, governors, senators, business owners, officers, CEO's of different companies etc. This is quite a change and so the question arises that: Do women express leadership in the same way as men? 
Whether men and women behave differently in leadership roles is a much-debated question. Although there is general agreement that women face more barriers to becoming leaders than men do, especially for leader roles that are male-dominated (Eagly \& Johans, 2001), there is much less agreement about the behavior of women and men once they attain such roles. This issue is usually discussed in terms of leadership styles, when style is understood as relatively stable patterns of behavior that are manifested by leaders. Differences in styles can be consequential because they are one factor that may affect people's views about whether women should become leaders and advance to higher positions in organizational hierarchies. To approach this issue, we first analyze traditional thinking about the leadership styles of women and men.

\section{Traditional Leadership}

Traditionally leadership has been studied since the emergence of civilization. One important reason for this is the very common assumption that leaders through their personal qualities, influence and actions profoundly shape societal events. According to Burns (1978) "Leadership is one of the most observed and least understood phenomena on earth". Leadership has been conceived as a matter of personality, as particular behaviours, as a matter of contingency, as a power relations, as the focus of group possesses, and in terms of multiple combinations of these variables. Leadership is socially constructed through the interaction of leaders and followers within a specific context and is equated with power. The basic concept of leadership has, in recent times, acquired exceptional pertinence and importance to organizations concerned with developing a strong work place culture and building high-performance human systems. The search for alternatives to the traditional Command and control leadership model has given rise to models variously labeled Transformational leadership (Tichy \& Devanna, 1986) Charismatic leadership (Conger, 1989) and Self-leadership (Manz \& Sims, 1987). In the present world Managers are looking for a style of leadership that will develop the firm's human endowment, generating employee commitment, flexibility, innovation and change (Bratton, Grint, Nelson, 2005).

\section{Transformational and Transactional Leadership}

The conventional relationship between leader and follower, rooted in the usual exchange of material rewards for effort, is often called transactional leadership. Burns divides leaders into transactional and transformational leaders. He defines transactional leadership as an exchange relationship in which the leader and the follower are engaged in some kind of trade or exchange, often economic, social and psychological (Burns (1978). 
In contrast transformational leadership is not an exchange process at all. A transformational leader appeals to his or her followers' sense of values beyond their own personal interests. Transformational leadership is "the capacity to bring about fundamental change that meets the aching wants and needs, the burning hopes and expectations of the people during critical moments in a nation's history"(Burns, 1978), all transformational leaders are charismatic, but not all charismatic are transformational leaders (Burns \& Sorenson, 1999).

Transformational leadership involves the following four elements: vision, values, communication and behavior. These four elements combined constitute an "ambient culture" within which leadership operates (Hooper \& Potter, 1997). The transactional and transformational factors are independent of each other - that is, a strong transactional leader may well prove to be a weak transformational leader (Bass, 1997). But strong transformational leaders are also likely to be strong transactional leaders (Hughes, 1999). In other words, leaders use all of these factors as related resources, and they tend to be good or bad across the entire range.

Although transformational and transactional styles are not as obviously related to gender roles as the leadership styles investigated by earlier researchers, transformational leadership has communal aspects, especially the theme of individualized consideration whereby leaders focus on the mentoring and development of their subordinates and pay attention to their individual needs. Consistent with the possibility that transformational leadership may be somewhat more aligned with the female than the male gender role are studies showing that subordinates perceive greater correspondence between leaders' feminine personality attributes and their transformational style than their transactional style (Hills, 1992).

In short, to the extent that gender roles spill over to influence leadership behavior in organizational settings, the behavior of female leaders, compared with that of male leaders, may be more interpersonally oriented, democratic, and transformational. In contrast, the behavior of male leaders, compared with that of female leaders, may be more task-oriented and autocratic. In addition, the greater incongruence of the female than male gender role with typical leader roles may make it more difficult for women than men to manifest the more agentic leadership styles (Eagly, et.al, 2001). However, because of the constraining impact of leadership roles, any differences between women and men who occupy the same role are unlikely to be large in size. 


\section{Fig.1 Charismatic, Transformational and Transactional Leadership ${ }^{1}$}

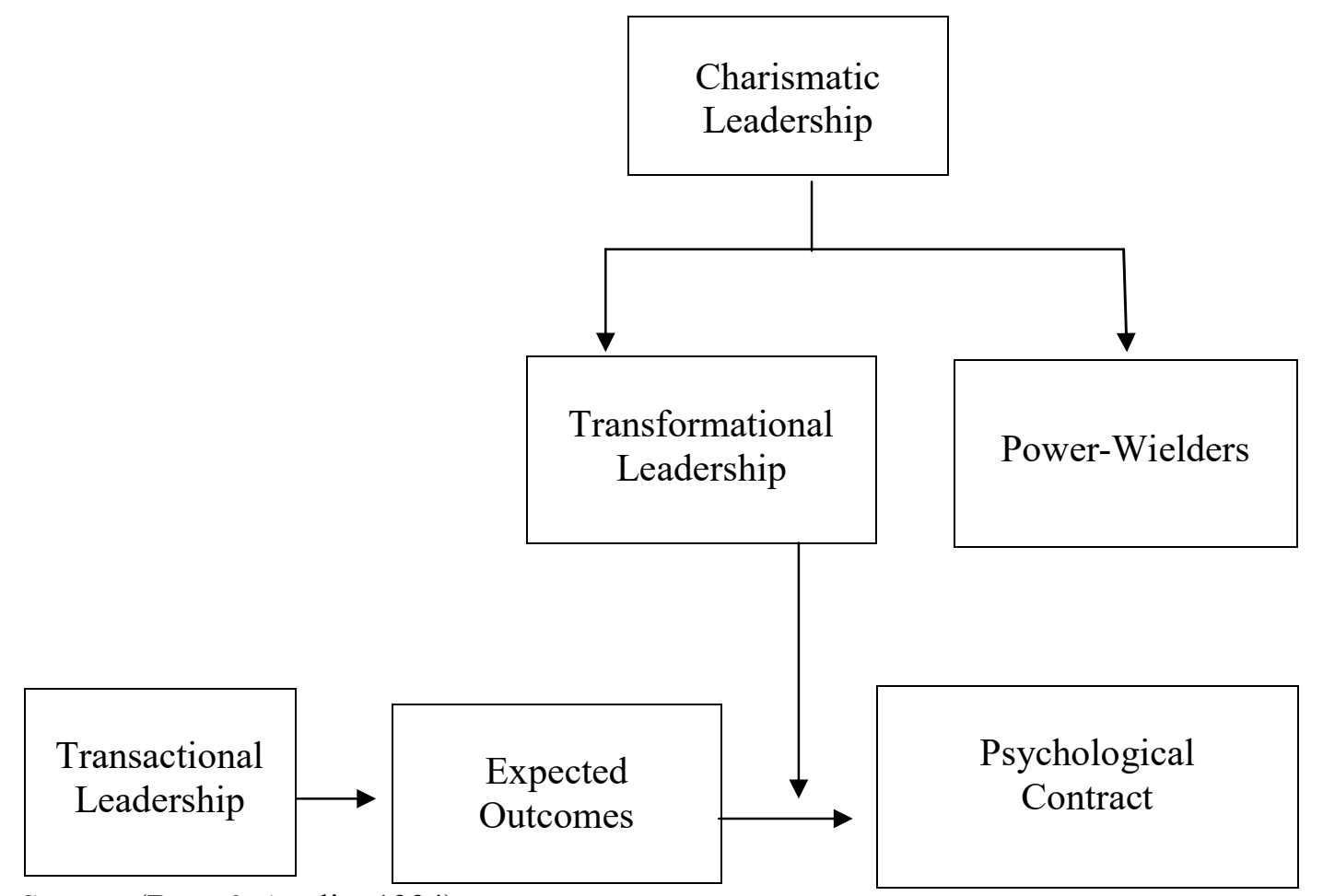

Source: (Bass \& Avolio, 1994)

\section{Charismatic Leadership}

There is no doubt that leadership plays a vital role in organizational formation and growth. A number of studies are conducted that have shown its dependency on surrounding cultural context, focused on particular behavioural characteristics, individual features etc. Charismatic leadership research has developed so far from 1980's, and led from individual characters to analyse its nature in the mirror of media, social environment and various other contextual up-to-date aspects. In leadership studies gender is nowadays used as a critical focus to understand its nature, whereas in charismatic leadership studies gender as a focus is not used so far.

Charisma, according to Collins English Dictionary, literally means, "a special personal quality or power of an individual making him or her capable of influencing or inspiring large numbers of people and a divinely bestowed power or talent". This conventional definition portrays people with charisma as having extraordinary personal qualities and the ability to persuade others to follow them, rather like the mythical Pied Piper of Hamlin. If charisma is indeed something that individuals have, then it should be objectively verifiable (Bratton, Grint, Nelson, 2005). Most of the researchers have 
implied that charisma is merely a personal characteristic that many people have and that some have more of than others - what we call "weak charisma". Charisma emerges only under certain situations - most notably when an audience is available. This implies that charisma is not a possession but a relationship, not something individuals have but something that others perceive or one can say that charisma lies in the eyes of the beholder. In sum, charismatic leadership appears to be not a psychological phenomenon but a sociological phenomenon - not a personal possession, but a social relationship (Bratton, Grint, Nelson, 2005).

According to Trice and Beyer (1986), Weber believed that charisma involves five related elements: 1. An individual of exceptional power or qualities, 2. A social crisis, 3. A radical solution to the crisis offered by the individual, 4. Devoted followers, attracted to the individual's transcendent power, 5. Repeated success. He believed that charisma could not be analysed along a continuum - either people were charismatic or not. Weber (1964) insisted that charismatics emerges only during periods of social crisis or "moments of distress", which encourages voluntary subordination by followers.

Bass (1999) suggests that the current developments on charisma have at least followed in the direction set by Weber, who moved the basis from theology to sociology. Charismatic leaders have "personal magnetism, spellbinding powers, and heroic qualities. They are passionate, driven individuals who are able to paint a compelling vision of the future (Hughes, Ginnett and Curphy (1999).

Overall, leadership charisma with its strong emphasis on individuality and autonomy looks to apply more to male character than to women - exactly the same way as there are fewer women as leaders in top positions of organizations all over the world. (Bratton, Grint, Nelson, 2005). Charismatic leadership is based on the emotions. It is irrational, as Weber put it. It is also interactive situation and relation, leader has power over his followers, but followers have power over the leader. The power becomes legitimised. The follower will obey in cases when his/her values are congruent with values of the leader. This is not coercion, but a voluntary action (Weber, 1964).

\section{Do Female and Male Leaders Differ?}

Throughout the ages, women have protested against their oppression in various ways, and intellectuals and sociologists have often drawn attention to women's plight (Evans, 1977). Almost over the last two decades, however, the topic of gender relations in the workplace has attracted much attention from academics, practitioners, and the popular management press and has entered the leadership literature. The entry of increasing numbers of women into management positions has generated more research on gender and leadership. Studies question among other things that what are the social factors keep women from 
breaking through the glass ceiling and whether women lead differently from men (Bratton, Grint, Nelson, 2005)?

It is a common belief that women lead is a more collaborative and democratic manner then men. If that is true, how can some experts on leadership maintain that male and female leaders do not differ at all as long as they have the same leadership positions? In fact, both of these ideas have an element of truth: many women lead with behaviours that are tinged with culturally feminine qualities. But male and female leaders differ only in some respects and some circumstances and on the whole, do not differ by much. All leaders have their typical modes of acting - their own distinctive styles.

Though, men and women differ little in the traits and abilities that are most relevant to leadership particularly, general intelligence, which is associated with leadership and is equal in men and women. Several scholars argue that women leaders have a more interactive style and behave in a more people-oriented, knowledge sharing, and participative manner than men in similar positions. Leadership characteristics associated with feminine leaders include consensus building, sharing power, and promotion of diversity. Men and women differ in some ethical qualities (Bratton, Grint, Nelson, 2005). Women, more than men, disapprove of a wide range of morally nontraditional behaviours and policies. This ethical theme is consistent with women's greater religiosity. Women also express more compassion for less-fortunate individuals and focus on implications for close relationships in resolving moral dilemmas (Eagly et.al., 2004). Behaviourally, women are less likely than men to engage in most types of criminal activity. All in all, women differ from men in several aspects of ethics and morality. Especially with heightened concern about ethics in business and politics, moral differences could give women an advantage as leaders. Some management researches have also suggested that including more women among executives should decrease fraud by top management (Zahra, Priem \& Rasheed, 2005).

But at the same time there are different reasons for thinking that men and women who are in the same role lead in similar ways. Male and female leaders are ordinarily selected by the same criteria and are required to have the same types of educational qualification. It is a fact that leader's behaviour is influenced by the roles that they occupy: certain ways of doing things are expected in certain roles. Therefore, women are under pressure to carry out task in the same ways as their male colleagues ( Bauer, Morrison \& Callister, 1998). Here the question arises that why do people have expectations about female leaders being communal? It is just because women leaders have the burden of negotiating two roles: as women and as leader. They have to reconcile the communal qualities that people prefer in women with the agnatic qualities that people think leaders need to exhibit to succeed. Finding an appropriate and effective leadership style is therefore a delicate task, and women can do it in a better way (Catalyst, 2001). 
Women generally split the difference between masculine and feminine demands by finding a middle way that is neither unacceptable masculine nor unacceptably feminine. Different studies regarding on-the-job behavior showing the influence of gender, friendly, people-oriented, and expressive behaviours were more common in women then men, regardless of their job status. And also showing the influence of work place roles, assertive, confident, and competent behaviours were more common in people who had higher- status jobs, regardless of their gender usually women in managerial roles- being both female and higher-status-blended assertive competence with supportive friendliness ( Moskowitz, Suh, and Desaulniers, 1994). But do men and women really differ in how they lead? To answer this query we have to look into different researches on leadership styles. As there are many studies which shown that some leaders have a relatively taskoriented style-emphasizing behaviour that accomplishes assigned task- and others have a more interpersonally oriented style-emphasizing behavior that maintain positive interpersonal relationship. Gender norms tend to steer male leaders towards a taskoriented style, and female leaders towards an interpersonally oriented style (Luthans, 1998).

\section{Feminist Approaches to Leadership}

Early feminist argued that individuals should possess equal opportunity regardless of gender that organizational appraisals should be gender-neutral, and that ability differences between women and men were the outcome of socialization and lack of opportunity rather than innate differences. Modern feminist theory suggests that women lead in a different way than men. Some feminist writings can be characterized as promoting a "feminine advantage" with the belief that women have the characteristics and skills necessary for more effective leadership. These skills and characteristics include a more interactional leadership style, the ability to build consensus, a tendency to empower others, and a greater ability to nurture others (Rosener, 1990). Female traits like sharing, intuition and nurturing compared favourably with stereotypical male traits like aggressiveness, dominance and rationality. Rosener suggested that women have a more consensual style of leadership and are more concerned with fostering shared vision, shared values and shared responsibilities. She also argued that women solicit input from others and operate not from the top of hierarchy but from the center of a circle - a position that allows them to be constantly in the information flow (Rosener, 1995). This makes employees feel important, creates loyalty, and places a focus on personal development. Feminist also believe that good relationship requires the characteristics of warmth, caring and empathy. Finally, the feminist approach involves a commitment to diversity, opposing discrimination based on gender, race or sexuality (Bratton, Grint, Nelson, 2005). Rosener also proposed that these feminine characteristics allow women to succeed because they are associated with transformational leadership, which inspires followers to reach high levels of performance (Rosener, 1990). 


\section{Age Discrimination}

Whether a women in young, old or somewhere in between, her age is a significant factor in how she is perceived in the workplace and in how she perceives herself. Usually, both the responses of others to her age and her own feelings about it differ from those of men of the same age-sometimes positively and sometimes negatively.

Maturity is the double-edged sword for women who aspire to leadership roles. Researches shows that people tend to look favourably upon older women - more so than upon older men- and to give them high performance ratings. On the other hand, although middle management of any organization preferred these women, who tended to be less aggressive, senior management wanted young, dynamic women for the top executive positions. Older women are seen by their supervisors as highly competent rather then the men of the same age. The other side of this phenomenon is that the younger women are not getting a good chance at top positions either, because their supervisors are not promoting them to middle-management positions. Sometimes, the myth and reality of the effects of age are widely divergent. It was also found that, although older female workers are perceived as less stable than younger women, and their absentee rate is lower too. Discrimination is one aspect of the effects of age, but women's own feelings about themselves as a result of age are an equally powerful force in how well do in her career. A women's age has an impact on how she is treated at work. It also is a factor in how she perceives herself. Older women, because their back grounds are likely to be traditional, sometimes lack the confidence that younger women have. On the other hand, a younger women's self-confidence may work against her if her male superiors perceive her as a threat (Jacobson, 1985). The women leaders today are therefore facing expectations and challenges beyond proportion. Success is still not easy, of course. But women who have overcome the cultural taboos are preventing women's work, who have faith in themselves and who try are succeeding. Perhaps, sociological changes, which are inevitably taking place, will help in the change of outlook and prospects of women leadership. It will however take unprecedented time and efforts to make women equal participants in leadership.

\section{Styles and Authority}

Successful women do not have to copy men slavishly in their leadership style. They do need to develop a range of techniques, but they can also adapt them to their own "womanly" styles. ${ }^{2}$ They do not have to abandon the warmth, compassion and different sense of values and time that women learn inorder to be effective women incharge. They can benefit both sexes if they bring a more human measure to the workplace. The important criteria are whether they feel comfortable and self-assured and are able to function effectively as compared to their male counterparts. The answer is; some women 
find it easier to fit into traditional models of authority, where as others find that they must adjust the mould slightly to fit their different social conditioning (Jacobson, 1985). Once women actually get power, they behave just as capable as men, and their styles of leadership cover the same range with no sex differentiation.

\section{Similarities between Female and Male Leadership Style}

The demand of leadership roles between male and female promote similarity in male and female leaders. Still, different researches show that among mangers in the same role, some sex differences have been detected. Women, more than men, have a democratic, participative and collaborative style. However, this tendency erodes somewhat when women are in male-dominated roles. Because women in senior management are not much in number, particularly in large corporations, they very often lead in much the same way as their male counterparts do (Eagly \& Carli, 2007). It is also a fact that female managers are slightly more likely to have a transformational style than male managers and also, women, more than men, use rewards to encourage appropriate behaviours. When women exhibit transformational leadership, it may be blended with participative, democratic behaviours (Eagly \& Carli, 2007).

When comparisons were made with their male counterparts, female leaders were found to be equally capable and competent. Many women leaders have been equally well educated and well trained and were regarded to be as well equipped with problem solving skills as men. They also have the potential of being as effectively trained and further developed as men for future contributions to performance.

All these differences in leadership styles that we discussed are merely average differences. Average differences tend to be small and do not appear in all types of leadership roles or in all nations. Research on leadership styles certainly provides no biases for denying women leadership opportunities on the ground that favour inappropriate styles. For many years leadership researches have urged managers to adopt transformational and collaborative style to manage the complexities of contemporary organizations. In fact, the cultural wave seems to be moving toward greater appreciation of leadership styles of this general type. To better understand the implications of the leadership styles of women and men we must need to take into account the organizations within which leadership typically takes place. It is unlikely that the future will bring continuous, even progress towards gender equality, with women steadily rising into leadership positions in a more or less linear progression. Yet it is a common perception that women will steadily gain greater access to leadership, including to elite positions of power. Women in the present world still face many challenges, especially in relation to male-dominated leadership roles. The women who find their way are the path-breakers of social change and they usually have figured out how to negotiate the twist more or less on their own. 


\section{Conclusion}

While thinking and finding out the answer of the question I have come to the point that women have always had the ability and aspiration for leadership but were not able to express their potential because of economic and societal constraints. Now that these constraints have been somewhat reduced women are able to be leaders. It has been suggested that women bring new leadership styles to the top roles in organizations and that the presence of women leaders in significant numbers may change some of our thinking about leadership. If leadership is evidenced by the transformation of people and organizations, women should be seen as leaders and if leadership consists in the management of relationships to achieve common goals, it will be interesting to see if the interpersonal skills of women will make them more effective leaders than their male counterparts.

\section{End Note}

1. Fig. 1 illustrates the connection among the various forms of leadership.

2. In the past, most women who succeeded in becoming leaders did so by adopting the masculine style of leadership. There are now indications that women are beginning to make an impact on organizations using their own style of leadership. Rosener (1990) has studied what she calls the second generation of managerial women. The first generation of female managers had to adhere to the same rules of conduct for success that applied to men. This new generation is making its way "not by adopting the style and habits that have proved successful for men but by drawing on what is unique to their socialization as women and creating a different path to the top".

\section{References}

Bass, B. M. (1999). On the Taming of Charisma: A Reply to Janice Beyer, Leadership Quarterly, 10(4), pp. 541-553.

Bass, B. M. (1997). Does the Transactional-Transformational Leadership Paradigm Transcend Organizational and National Boundaries? American Psychologist 52(3), pp. 130-130.

Bass, B. M. \& Avolio, B. J. (eds.) (1994). Iincreasing Organizational Effectiveness through Transformational Leadership, Thousand Oaks, CA, Sage. 
Bauer, T.N., Morrison, E.W. \& Callister, R.R. (1998). Organizational Socialization: A Review and Directions for Future Research, Research in Personnel and Human Resources Management, 16, 149-214.

Bratton,John, Grint, keith, \& Nelson,Debra L. (2005). Organizational Leadership, Ohio, Thomson.

Burns, J.M., \& Sorenson, A.J. (1999). Dead Center: Clinton-Gore Leadership and the Perils of Moderation, London, Prentice Hall.

Burns, J. M. (1978). Leadership, New York, Harper \& Row.

Catalyst (2001). The Next Generation: Today's Professionals, Tomorrow's Leaders, New York, Catalyst.

Conger, J.A (1989). The Charismatic Leader: Behind the Mystique of Exceptional Leadership, San Francisco, Jossey-Bass Publishers.

Eagly, A. H. \& Carli,L. (2007). Through the Labyrinth, Boston, Harvard Business School Press.

Eagly, A. H. et.al., (2004). Gender Differences, Retrieved on July, 15, 2011, http://www. enotes.com/topic/Gender differences.

Eagly, Alice H. \& Johannesen-Schmidt, Mary C. (2001). "The Leadership Style of Women and Men", Journal of Social Issues,57(4), pp781-797.

Evans, Richard J. (1977). The Feminist, London, Croom-Helm.

Hills, M (1992). The Panel Study of Income Dynamics: A User's Guide, Newbury Park, CA, Sage.

Hooper, A. \& Potter, J. (1997). The Business of Leadership, Aldershot, UK, Ashgate.

Hughes, R, L., Ginnett, R. C. \& Curphy, G. J. (1999). Leadership: Enhancing the Lessons of Experience, Singapore, Irwin-McGraw-Hill.

Jacobson, Aileen (1985). Women Incharge:Dilemmas of Women in Authority, New York, Van Nostrand Reinhold Company.

Luthans, F., \& Stajkovic, A. (1998). "Self-efficacy and Work-related Performance: A Meta- Analysis", Psychological Bulletin, 124, pp 240-261. 
Manz Charles C. \& Sims,H.P. (1987). "Leading Workers to Lead Themselves: The External Leadership of Self- Managing Work Teams", Administrative Science Quarterly, 32(1).

Moskowitz, D. S.; Suh, Eun Jung; Desaulniers, Julie (April, 1994). Situational Influences on Gender Differences in Agency and Communion, Journal of Personality and Social Psychology, 66(4), pp 753-761.

Rosener, J. B. (1995). America's Competitive Secret: Utilizing Women as a Management Strategy, New York, Oxford.

Rosener, J. B. (1990). Ways women lead, Harvard Business Review, 68(6), 119-125

Sogra, Khair Jahan (1994). Women in Management: Champions of Change, Dhaka, University Press Limited.

Stogdill, R.M. (1974). Handbook of Leadership: A Survey of the Literature, New York, Free Press. McC.

Tichy, Noel M. \& Devanna,Mary Anne (1986). The Transformational Leader, New York, Wiley.

Trice, H. M., \& Beyer, J. M. (1986). Charisma and its Routinization in Two Social Movement Organizations, Research in Organizational Behaviour, 8, pp.113-164.

Weber M. (1964). The Theory of Social Economic Organization, New York, Yhe Free Press.

Zahra, Shaker, Priem, Richard, \& Rasheed,Abdul (2005). The Antecedents and Consequences of Top Management Fraud, Journal of Management,31(4), pp 803-828.

Asma Manzoor is Co-operative Teacher in the Centre of Excellence for Women's Studies, University of Karachi.

Prof. Dr. Naheed Abrar is Chairperson in the Department of Social Work, Urdu University, Karachi. 